Article

\title{
Copper, Iron and Aluminium Electrochemical Corrosion Rates and Intrinsic Diffusivitives Dependence on Temperature Investigations
}

\author{
Mykhaylo V. Yarmolenko
}

Kyiv National University of Technologies and Design, Faculty of Market, Information and Innovation Technologies, Cherkasy, Ukraine, e-mail: yarmolenko.mv@knutd.edu.ua

\begin{abstract}
Our investigations show that electrochemical corrosion of copper is faster than electrochemical corrosion of aluminium at temperatures below $100^{\circ} \mathrm{C}$. Literature data analysis shows that the $\mathrm{Al}$ atoms diffuse faster than the $\mathrm{Cu}$ atoms at temperatures higher than $475^{\circ} \mathrm{C}, \mathrm{Al}$ rich intermetallic compounds (IMCs) are formed faster in the $\mathrm{Cu}-\mathrm{Al}$ system, and the Kirkendall plane shifts toward Al side. Electrochemical corrosion occurs due to electric current and due to diffusion. An electronic devise working time, for example, depends on initial copper cover thickness on aluminium wire, connected to the electronic devise, temperature, and volume and dislocation pipe diffusion coefficients, so copper, iron, and aluminium electrochemical corrosion rates are investigated experimentally at room temperature and at temperature $100^{\circ} \mathrm{C}$. Intrinsic diffusivities ratios of copper and aluminium at different temperatures and diffusion activation energies in the $\mathrm{Cu}-\mathrm{Al}$ system are calculated by proposed here methods using literature experimental data. Dislocation pipe and volume diffusion activation energies of pure iron are calculated separately by earlier proposed method using literature experimental data. Aluminium dissolved into $\mathrm{NaCl}$ solution as the $\mathrm{Al}^{3+}$ ions at room temperature and at temperature $100^{\circ} \mathrm{C}$, iron dissolved into $\mathrm{NaCl}$ solution as the $\mathrm{Fe}^{2+}\left(\right.$ not $\left.\mathrm{Fe}^{3+}\right)$ ions at room temperature and at temperature $100^{\circ} \mathrm{C}$, copper dissolved into $\mathrm{NaCl}$ solution as the $\mathrm{Cu}^{+}$ions at room temperature and as the $\mathrm{Cu}^{+}$and the $\mathrm{Cu}^{2+}$ ions at temperature $100^{\circ} \mathrm{C}$. It is founded experimentally that copper corrosion is higher than aluminium corrosion, and ratio of electrochemical corrosion rates, $k_{C u} / k_{A l}>1$, decreases with temperature increasing, although iron electrochemical corrosion rate doesn't depend on temperature below $100^{\circ} \mathrm{C}$. It is obvious, because melting point of iron is more higher then melting point of copper or aluminium. It is calculated that copper electrochemical corrosion rate is approximately equal to aluminium electrochemical corrosion at temperature about $300^{\circ} \mathrm{C}$, so copper can dissolve into $\mathrm{NaCl}$ solution mostly as the $\mathrm{Cu}^{2+}$ ions at temperature about $300^{\circ} \mathrm{C}$. Ratio of intrinsic diffusivities, $D_{C u} / D_{A l}$ $<1$, increases with temperature increasing, and intrinsic diffusivity of aluminium could be approximately equal to intrinsic diffusivity of copper at temperature about $460^{\circ} \mathrm{C}$.
\end{abstract}

Keywords: electrochemical corrosion, metallic coatings, electrolysis, diffusion, intermetallic compounds, phases formation kinetics, copper, aluminium, iron, Kirkendall-Frenkel porosity, Kirkendall shift, activation energy

\section{Introduction}

An Al wire coated with thin Cu cover ( $\approx 15 \mu$ m thickness), utilized near an automobile motor, is heated to temperatures about $373-473 \mathrm{~K}\left(100-200^{\circ} \mathrm{C}\right)$. Intermetallics (IMCs) can formed at the $\mathrm{Cu} / \mathrm{Al}$ interface and grow gradually during heating at such temperatures. The IMC layers are brittle and have high resistivity. Therefore, for assurance of the reliability of the product, information on the growth behaviour of the IMC layers during heating is essentially important [1]. Figure 1 shows the problem: an electronic devise working time, $t_{0}$, depends on initial $\mathrm{Cu}$ cover thickness, $\mathrm{X}_{\mathrm{Cu}}$, and temperature. Electric 
conductivity of copper is higher than electric conductivity of aluminium in approximately two times, but the formation of intermetallic phases induce significant increase in contact resistance which is found to increase linearly with the thickness of the intermetallics formed [20]. The temperature range used to produce the intermetallic phases was from 250 to $515^{\circ} \mathrm{C}$. Moreover, the presence of an electrical field greatly accelerated the kinetics of formation of intermetallic phases and altered significantly their morphology, and the impaired mechanical integrity of the $\mathrm{Al}-\mathrm{Cu}$ bimetallic joints treated by an electrical current was clearly demonstrated by an extensive cracking not only across the whole intermetallic bandwidth but also within different phases and at a neighbouring interface [20]. Three phases thickness, $X_{123}$, can be estimated in such a way. The mass conservation law gives:

$$
X_{C u}(t=0) \cdot 1=\frac{9}{9+4} X_{3}\left(t_{0}\right)+\frac{1}{1+1} X_{2}\left(t_{0}\right)+\frac{1}{1+2} X_{3}\left(t_{0}\right) \approx \frac{1.526 X_{123}}{3} \approx 0.509 X_{123}, \text { and } X_{123} \approx 2 X_{C u}
$$

so three phases general thickness is approximately greater in two times than initial $\mathrm{Cu}$ cover thickness.

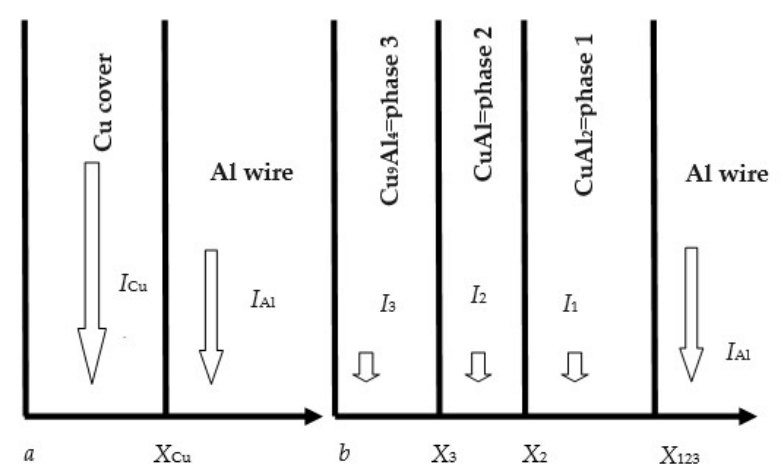

Figure 1. (a) Initial stage ( $t=0)$ : an electronic devise is working, since the electric current, $I_{a}=I_{\mathrm{Cu}}+I_{\mathrm{Al}}$, has optimal value; $(b)$ final stage $\left(t=t_{0}\right)$ : the electronic devise isn't working, because the electric current, $I_{b}=I_{3}+I_{2}+I_{1}+I_{\mathrm{Al}}$, has too small value, since pure $\mathrm{Cu}$ cover has disappeared.

Otherwise, it was proved experimentally that thin $\mathrm{Al}$ pad $(\approx 1 \mu \mathrm{m}$ thickness $)$ can prevent gold and copper corrosion, because intermetallics formation rate in Au-Al system is much more higher than intermetallics formation rate in $\mathrm{Cu}-\mathrm{Al}$ system, so it is possible to use $\mathrm{Cu}$ instead of $\mathrm{Au}$ for wire bonding in microelectronics packaging, and $\mathrm{Cu}$ has higher electric conductivity, higher thermal conduction, and lower material cost than $\mathrm{Au}$ [2]. Corrosion and intermetallics rate formation in gold and copper wire bonding in microelectronics packaging were investigated in [2] at temperatures $T_{1}=175{ }^{\circ} \mathrm{C}, \mathrm{T}_{2}=200{ }^{\circ} \mathrm{C}$, and $T_{3}=225{ }^{\circ} \mathrm{C}$ during $120,240,360$, and $480 \mathrm{~h}$. The authors have reported that crosssectional analysis of the $\mathrm{Cu}$ ball on $\mathrm{Al}$ pad confirmed that corrosion occurred at temperatures about $\mathrm{T}=200^{\circ} \mathrm{C}$ primarily beneath the $\mathrm{Cu}$ balls and did not initiate from the $\mathrm{Al}$ pad, formation of $\mathrm{CuCl}_{2}$ didn't allow self-passivation of $\mathrm{Cu}$ to occur, so rate of copper corrosion increased, and the rate of $\mathrm{Cu}-\mathrm{Al}$ intermetallics formation was found to be three to five times slower than $\mathrm{Au}-\mathrm{Al}$ intermetallics formation at all three annealing temperatures. So, copper dissolved into $\mathrm{NaCl}$ solution as $\mathrm{Cu}^{2+}$ ions at temperatures about $T=200^{\circ} \mathrm{C}$, as we expected. They didn't investigate corrosion rates dependence of copper and aluminium on temperature. Moreover, phase layers general thicknesses for $\mathrm{Cu}-\mathrm{Al}$ system were calculated [2]:

$$
X_{123}^{2}=K_{123} t+K_{01}=K_{0} e^{-Q /(R T)}+K_{01}=3.52 \cdot 10^{-4 \mu m^{2}} / \mathrm{s} \cdot e^{-25500 \mathrm{Jmol}^{-1} /(R T)} t+0.44 \mu \mathrm{m}^{2},
$$


where $\mathrm{R} \approx 8.314 \mathrm{JK}^{-1}$ is the gas constant, $\mathrm{K}_{01}$ is constant related to initial IMC thickness. General reaction rates of IMC formation were calculated: $\mathrm{K}_{123}\left(\mathrm{~T}_{1}\right)=3.57 \cdot 10^{-7} \mu^{2} / \mathrm{s}$, $\mathrm{K}_{123}\left(\mathrm{~T}_{2}\right)=6.26 \cdot 10^{-7} \mu \mathrm{m}^{2} / \mathrm{s}$, and $\mathrm{K}_{123}\left(\mathrm{~T}_{3}\right)=7.15 \cdot 10^{-7} \mu \mathrm{m}^{2} / \mathrm{s}$. The pre-exponential factor and IMC formation activation energy were calculated: $\mathrm{K}_{0} \approx 3.52 \cdot 10^{-4} \mu \mathrm{m}^{2} / \mathrm{s}, \mathrm{Q} \approx 25.5 \mathrm{~kJ} / \mathrm{mol}$. We can use these results to calculate the electronic devise working time by equation (11) in [3] at different temperatures:

$$
\begin{gathered}
t_{0} \approx \frac{X_{C u}^{2}}{C_{3}^{2} K_{123}}=\frac{169}{81} \frac{X_{C u}^{2}}{K_{123}} \approx \frac{2 X_{C u}^{2}}{K_{0}} e^{Q /(R T)} \approx 5900 \cdot X_{C u}^{2}\left[\mu m^{2}\right] \cdot e^{25.5 \mathrm{kJmol} / 1 /(R T)} \mathrm{s} \\
t_{0}\left(T_{1}=175^{\circ} \mathrm{C}=448 \mathrm{~K}\right) \approx 5900 \cdot 225 \cdot e^{25500 /(8.314 \cdot 448)} \mathrm{s} \approx 40 \text { years } ; t_{0}\left(T_{2}=200^{\circ} \mathrm{C}\right) \approx 28 \text { years } ; \\
t_{0}\left(T_{3}=225^{\circ} \mathrm{C}\right) \approx 21 \text { years } ; t_{0}\left(T_{4}=300^{\circ} \mathrm{C}\right) \approx 9 \text { years } ; t_{0}\left(T_{5}=350^{\circ} \mathrm{C}\right) \approx 6 \text { years } .
\end{gathered}
$$

Other researchers have obtained [15]: $\mathrm{K}_{123}\left(\mathrm{~T}_{4}=300^{\circ} \mathrm{C}\right)=4.2 \cdot 10^{-4} \mu \mathrm{m}^{2} / \mathrm{s}, \mathrm{K}_{123}\left(\mathrm{~T}_{5}=350^{\circ} \mathrm{C}\right)=3.4 \cdot 10^{-}$ ${ }^{3} \mu \mathrm{m}^{2} / \mathrm{s}$. Equation (3) gives:

$$
t_{0}\left(T_{4}=300^{\circ} C\right) \approx \frac{2 X_{C u}^{2}}{K_{123}} \approx 12 \text { days } \quad t_{0}\left(T_{5}=350^{\circ} C\right) \approx \frac{2 X_{C u}^{2}}{K_{123}} \approx 1.5 \text { days }
$$

We can calculate: $\mathrm{Q} \approx 124 \mathrm{~kJ} / \mathrm{mol} ; \mathrm{K}_{0} \approx 8.5 \cdot 10^{-5} \mathrm{~m}^{2} / \mathrm{s}=8.5 \cdot 10^{7} \mu \mathrm{m}^{2} / \mathrm{s}$;

$$
\begin{gathered}
t_{0}\left(T=175^{\circ} C\right) \approx 5.3 \cdot 10^{-6} \cdot e^{124 \mathrm{Jmol}^{-1} /(448 R)} s \approx 49 \text { years } ; \quad t_{0}\left(T=200^{\circ} C\right) \approx 8.4 \text { years } \\
t_{0}\left(T=225^{\circ} C\right) \approx \frac{2 X_{C u}^{2}}{K_{0}} e^{Q /(R T)} \approx 5.3 \cdot 10^{-6} \cdot e^{124 \mathrm{Jmol}^{-1} /(498 \mathrm{R})} \mathrm{s} \approx 1.7 \text { years }
\end{gathered}
$$

It was reported in [1] that the growth of layer 1 is controlled predominantly by boundary diffusion, but that of layers 2 and 3 are governed mainly by volume diffusion at temperatures $\mathrm{T}=483-543 \mathrm{~K}\left(210-270^{\circ} \mathrm{C}\right)$ for various periods up to $3.456 \mathrm{Ms}(960 \mathrm{~h})$. The authors obtained: $\mathrm{K}_{01} \approx 5.3 \cdot 10^{-7} \mathrm{~m}^{2} / \mathrm{s}, \mathrm{Q}_{1} \approx 86 \mathrm{~kJ} / \mathrm{mol}, \mathrm{K}_{023} \approx 4.2 \cdot 10^{-5} \mathrm{~m}^{2} / \mathrm{s}, \mathrm{Q}_{23} \approx 146 \mathrm{~kJ} / \mathrm{mol}$. We can calculate: $\mathrm{K}_{123}\left(\mathrm{~T}_{6}=210^{\circ} \mathrm{C}\right)=1.5 \cdot 10^{-6} \mu \mathrm{m}^{2} / \mathrm{s}$,

$$
t_{0}\left(T=210^{\circ} C\right) \approx \frac{2 X_{C u}^{2}}{K_{123}} \approx 9.6 \text { years }
$$

The less temperature is, the higher contribution of grain-boundary diffusion and dislocation pipe diffusion to the layers growth is, so models of grain-boundary diffusion and dislocation pipe diffusion involving outflow into volume should be taken into account $[11,17,19]$.

Diffusion activation energy of $\mathrm{Al}$ is less than diffusion activation energy of $\mathrm{Cu}$ $\left(\mathrm{Q}_{\mathrm{Al}}<\mathrm{Q}_{\mathrm{Cu}}\right)$ at temperatures from $160^{\circ} \mathrm{C}$ to $250^{\circ} \mathrm{C}$ for mutual diffusion in copper-aluminium thin film double layers, but the pre-exponential factors are different in tens times [14]:

$$
D_{A l}^{*}=4 \cdot 10^{-5} e^{-121 \mathrm{kJmol}^{-1} /(R T)} \mathrm{m}^{2} / \mathrm{s}, \quad D_{C u}^{*}=9.5 \cdot 10^{-4} e^{-135 \mathrm{kJmol}^{-1} /(R T)} \mathrm{m}^{2} / \mathrm{s},
$$

in $\theta$-phase (phase 1) $\mathrm{CuAl}_{2}, C_{A l}=2 / 3 \approx 0.67, C_{C u}=1 / 3 \approx 0.33$;

$$
D_{A l}^{*}=1.5 \cdot 10^{-11} e^{-68 \mathrm{kJmol}^{-1} /(R T)} \mathrm{m}^{2} / \mathrm{s}, \quad D_{C u}^{*}=1 \cdot 10^{-6} e^{-106 \mathrm{kJmol}^{-1} /(R T)} \mathrm{m}^{2} / \mathrm{s},
$$


in $\eta_{2}$-phase (phase 2) $\mathrm{CuAl}, C_{A l}=C_{C u}=1 / 2=0.5$;

$$
D_{A l}^{*}=1.7 \cdot 10^{-7} e^{-116 \mathrm{kJmol}^{-1} /(R T)} \mathrm{m}^{2} / \mathrm{s}, D_{\mathrm{Cu}}^{*}=2.4 \cdot 10^{-6} e^{-125 \mathrm{kJmol}-1 /(R T)} \mathrm{m}^{2} / \mathrm{s},
$$

in $\gamma_{2}$-phase (phase 3) $\mathrm{Cu}_{9} \mathrm{Al}_{4}, \mathrm{C}_{A l}=4 / 13 \approx 0.31, \mathrm{C}_{\mathrm{C}}=9 / 13 \approx 0.69$.

We can calculate mutual diffusion coefficient for each phase at temperature $160^{\circ} \mathrm{C}$ by the Darken equation [21,19] and taking into account Eqs. (4)-(6):

$D_{i}^{*}=C_{A l} D_{C u}^{*}+C_{C u} D_{A l}^{*} ; i=1,2,3 ; \quad D_{1}^{*}=6.64 \cdot 10^{-20} \mathrm{~m}^{2} / \mathrm{s} ; D_{2}^{*}=1.3 \cdot 10^{-19} \mathrm{~m}^{2} / \mathrm{s} ; D_{3}^{*}=1.8 \cdot 10^{-21} \mathrm{~m}^{2} / \mathrm{s}$.

We can calculate using the methods described in $[3,4]: \mathrm{K}_{123}\left(\mathrm{~T}_{7}=160^{\circ} \mathrm{C}\right) \approx 2.8 \cdot 10^{-6} \mathrm{\mu m}^{2} / \mathrm{s}$, $t_{0}\left(T=160^{\circ} C\right) \approx \frac{2 X_{C u}^{2}}{K_{123}} \approx 5$ years, so the problem remains unsolved.

It was founded experimentally, that copper electrochemical corrosion is higher than aluminium electrochemical corrosion in approximately two times at room temperature $[3,4]$, so thin Al layer can prevent copper electrochemical corrosion. It was reported also about influence of hydrogen and absence of passive layer on corrosive properties of aluminium alloys [5].

Besides, the soldered copper/tin based contacts are the weakest part of the chip that can be related to intermetallics and the Kirkendall-Frenkel porosity formation in the contact zone [6]. One of the most common reasons for chip failure is the soldered. The typical range of packaging and operation of the integrated circuits is from room temperature to $250^{\circ} \mathrm{C}[7]$.

Hydrostatic pressure of Argon gas ( $\approx 10 \mathrm{MPa}$ ) can decrease Kirkendal-Frenkel porosity formation, but practically can't decrease mutual diffusion coefficients, but hot isostatic pressing ( $\mathrm{p} \approx 100 \mathrm{MPa}$, Argon) removes porosity due to homogenisation heat treatment in alloy CMSX4 and superalloy CMSX10 [8].

It was clarified also that carbon steel-stainless steel with the environment of flowing sodium chloride does indeed produce synergetic corrosion instead of antagonistic corrosion [9].

Electric current can destruct wire bonding in microelectronics packaging, so we planned to investigate copper, iron, and aluminium electrochemical corrosion at room temperature and at temperature $100^{\circ} \mathrm{C}$. Direct current can dissolve metal anode into electrolyte, and we planned to do experiments under the same conditions: initial radii of $\mathrm{Cu}$, $\mathrm{Fe}$, and $\mathrm{Al}$ anodes should be approximately equal, electrolyte concentration should be the same, anodes lengths immersed into electrolyte should be equal, graphite cathodes should be the same, direct electric current value should be practically the same. Aluminium can dissolve into electrolyte only as the $\mathrm{Al}^{3+}$ ions, so the charge of aluminium ions should be exactly equal to 3 , but copper can dissolve into electrolyte as the $\mathrm{Cu}^{+}$ions and the $\mathrm{Cu}^{2+}$ ions, and the charge of copper ions could be equal to 1 or 2 , and iron can dissolve into electrolyte as the $\mathrm{Fe}^{2+}$ ions and the $\mathrm{Fe}^{3+}$ ions, and the charge of iron ions could be equal to 2 or 3 . We need to find appropriate mathematical equations to calculate the charges of copper, iron, and aluminium ions dissolved into $\mathrm{NaCl}$ solution.

\section{Experimental results of copper, iron, and aluminium electrochemical corrosion}

\subsection{Investigation at room temperature}

Cylindrical anodes $(99.99 \% \mathrm{Cu}, 99.96 \% \mathrm{Fe}$, and $99.99 \% \mathrm{Al})$ were used for copper and aluminium [3,4], and also iron electrochemical corrosion investigation. Sodium chloride $(\mathrm{NaCl})$ solution was used as electrolyte (Figure 2). 


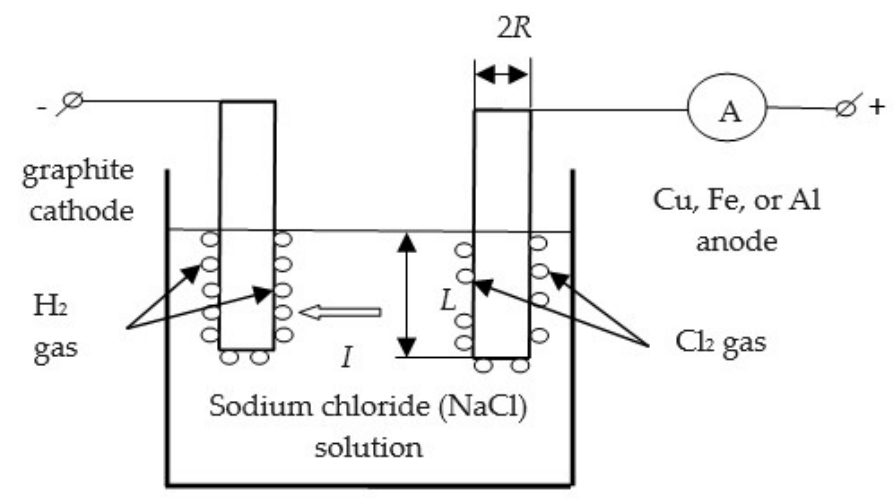

Figure 2. Scheme of experimental equipment at room temperature. $\mathrm{Cu}, \mathrm{Fe}$, and $\mathrm{Al}$ anodes dissolve into $\mathrm{NaCl}$ solution as $\mathrm{Cu}^{+}, \mathrm{Fe}^{2+}$, and $\mathrm{Al}^{3+}$ ions.

Direct electric current and anodes mass decreasing were measured. First of all, we need to be assured that the $\mathrm{Cu}^{+}$ions (or the $\mathrm{Cu}^{2+}$ ), the $\mathrm{Fe}^{2+}$ (or the $\mathrm{Fe}^{3+}$ ), and the $\mathrm{Al}^{3+}$ were present in $\mathrm{NaCl}$ solution. Rate of anode dissolving into electrolyte can be calculated using Faraday's law of electrolysis:

$$
\frac{d m}{d t}=\frac{M I}{z F}, d m=\rho \cdot L \cdot \pi \cdot d\left(R^{2}(t)\right) .
$$

Here $m$ is anode mass dissolved into electrolyte, $t$ is time of experiment, $M$ is molar mass, $I$ is direct electric current value, $F$ is the Faraday constant $\left(F \approx 96500 \mathrm{C} \mathrm{mol}^{-1}\right), z$ is charge of ions, $R$ is anode radius, $L$ is anode length immersed into electrolyte. Electric current value did not change, so one can calculate:

$$
z=\frac{M I t}{F \pi \rho L\left(R^{2}(t=0)-R^{2}(t)\right)},
$$

where $\rho$ is anode density. Charges of copper, iron, and aluminium ions were calculated:

$$
\begin{gathered}
z_{C u}=\frac{63.55 \cdot 10^{-3} \mathrm{~kg} / \mathrm{mol} \cdot 2.8 \mathrm{~A} \cdot 1.2 \cdot 10^{3} \mathrm{~s}}{F \cdot \pi \cdot 8.9 \cdot 10^{3} \mathrm{~kg} / \mathrm{m}^{3} L_{\mathrm{Cu}} \cdot\left(R_{C u}^{2}(t=0)-R_{C u}^{2}\left(t_{4}\right)\right)} \approx 0.995 \approx 1, \\
z_{A l}=\frac{27 \cdot 10^{-3} \mathrm{~kg} / \mathrm{mol} \cdot 3.1 \mathrm{~A} \cdot 1.2 \cdot 10^{3} \mathrm{~s}}{F \cdot \pi \cdot 2.7 \cdot 10^{3} \mathrm{~kg} / \mathrm{m}^{3} L_{A l} \cdot\left(R_{A l}^{2}(t=0)-R_{A l}^{2}\left(t_{4}\right)\right)} \approx 2.954 \approx 3, \\
z_{\mathrm{Fe}}=\frac{55.847 \cdot 10^{-3} \mathrm{~kg} / \mathrm{mol} \cdot 3.15 \mathrm{~A} \cdot 1.2 \cdot 10^{3} \mathrm{~s}}{F \cdot \pi \cdot 7.86 \cdot 10^{3} \mathrm{~kg} / \mathrm{m}^{3} L_{\mathrm{Fe}} \cdot\left(R_{\mathrm{Fe}}^{2}(t=0)-R_{\mathrm{Fe}}^{2}\left(t_{4}\right)\right)} \approx 2.03 \approx 2,
\end{gathered}
$$

where $L_{\mathrm{Cu}} \approx L_{\mathrm{Al}} \approx L_{\mathrm{Fe}}: L_{\mathrm{Cu}}=L_{\mathrm{Fe}}=5 \cdot 10^{-2} \mathrm{~m}, L_{\mathrm{Al}}=4.5 \cdot 10^{-2} \mathrm{~m} ; R_{0 \mathrm{Cu}}=R_{0 \mathrm{Al}}=2.8 \mathrm{~mm}, R_{0 \mathrm{Fe}}=2.98 \mathrm{~mm}$; $I_{\mathrm{Al}} \approx I_{\mathrm{Cu}} \approx I_{\mathrm{Fe}}: I_{\mathrm{Fe}}=3.15 \mathrm{~A}, I_{\mathrm{Al}}=3.1 \mathrm{~A}, I_{\mathrm{Cu}}=2.8 \mathrm{~A}, \quad$ so copper dissolved into $\mathrm{NaCl}$ solution as the $\mathrm{Cu}^{+}$ions, iron dissolved into $\mathrm{NaCl}$ solution as the $\mathrm{Fe}^{2+}$ ions, and aluminium dissolved into $\mathrm{NaCl}$ solution as the $\mathrm{Al}^{3+}$ ions. Anodes radii decreasing kinetics is shown on Figure 2. Experiments were carried during $t_{1}=5 \mathrm{~min}, t_{2}=10 \mathrm{~min}, t_{3}=15 \mathrm{~min}$, and $t_{4}=20 \mathrm{~min}$. 
Experimental results are as follows: $R_{1 \mathrm{Cu}}=2.74 \mathrm{~mm}, R_{2 \mathrm{Cu}}=2.67 \mathrm{~mm}, R_{3 \mathrm{Cu}}=2.59 \mathrm{~mm}, R_{4 \mathrm{Cu}}=2.5$ $\mathrm{mm} ; R_{1 \mathrm{Al}}=2.77 \mathrm{~mm}, R_{2 \mathrm{Al}}=2.73 \mathrm{~mm}, R_{3 \mathrm{Al}}=2.68 \mathrm{~mm}, R_{4 \mathrm{Al}}=2.62 \mathrm{~mm}, R_{1 \mathrm{Fe}}=2.95 \mathrm{~mm}, R_{2 \mathrm{Fe}}=2.92$ $\mathrm{mm}, R_{3 \mathrm{Fe}}=2.88 \mathrm{~mm}, R_{4 \mathrm{Fe}}=2.83 \mathrm{~mm}$. Measurement precision was $0.01 \mathrm{~mm}$ or 10 micrometers.

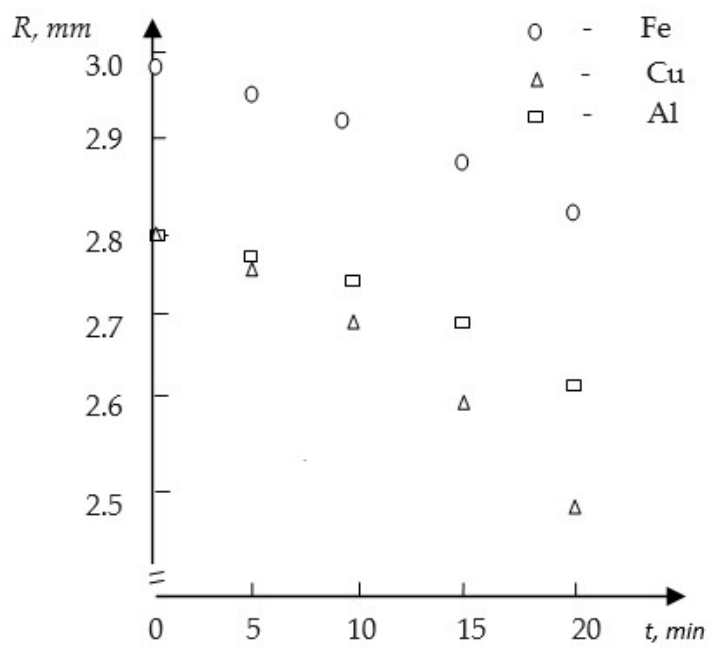

Figure 3. $\mathrm{Cu}, \mathrm{Fe}$, and $\mathrm{Al}$ anodes radii decreasing kinetics at room temperature.

Chemical reactions took place near positive electrode (anode):

$$
\begin{gathered}
C u^{0}-e^{-}=C u^{+}, \quad \mathrm{Al}^{0}-3 e^{-}=\mathrm{Al}^{3+}, \quad \mathrm{Fe}^{0}-2 e^{-}=\mathrm{Fe}^{2+} ; \\
\mathrm{Cu}^{+}+C l^{-}=\mathrm{CuCl} \downarrow, \mathrm{Al}^{3+}+3 \mathrm{Cl}^{-}=\mathrm{AlCl}_{3} \downarrow, \mathrm{Fe}^{2+}+2 \mathrm{Cl}^{-}=\mathrm{FeCl}_{2} \downarrow ; \\
\mathrm{Cl} l^{-}-e^{-}=\mathrm{Cl}^{0}, \mathrm{Cl}^{0}+\mathrm{Cl}^{0}=\mathrm{Cl}_{2} \uparrow .
\end{gathered}
$$

Chlorine gas was formed near anode.

Chemical reactions took place near negative electrode (cathode):

$$
\mathrm{Na}^{+}-e^{-}=\mathrm{Na}^{0}, \quad 2 \mathrm{Na}+2 \mathrm{H}_{2} \mathrm{O}=2 \mathrm{NaOH}+\mathrm{H}_{2} \uparrow \text {. }
$$

Hydrogen gas was formed near cathode.

Anodes radii decreasing rate constants can be calculated as average value of four experiments to increase calculation precise:

$$
\begin{gathered}
k_{\mathrm{Cu}}=\frac{4 R_{0}^{2}-\sum_{i=1}^{4} R_{i}^{2}}{\sum_{i=1}^{4} t_{i}} \approx 1.25 \cdot 10^{-9} \mathrm{~m}^{2} / \mathrm{s} \quad k_{A l}=\frac{4 R_{0}^{2}-\sum_{i=1}^{4} R_{i}^{2}}{\sum_{i=1}^{4} t_{i}} \approx 7.29 \cdot 10^{-10} \mathrm{~m}^{2} / \mathrm{s} \\
k_{\mathrm{Fe}}=\frac{4 R_{0 \mathrm{Fe}}^{2}-\sum_{i=1}^{4} R_{i F e}^{2}}{\sum_{i=1}^{4} t_{i}} \approx 7.26 \cdot 10^{-10} \mathrm{~m}^{2} / \mathrm{s}, \quad k_{\mathrm{Cu}} \approx 1.71 k_{A l} ; k_{A l} \approx k_{\mathrm{Fe}},
\end{gathered},
$$

so copper electrochemical corrosion is much more higher than aluminium and iron electrochemical corrosion, despite of $I_{\mathrm{Fe}} \approx I_{\mathrm{Al}} \geq I_{\mathrm{Cu}}: I_{\mathrm{Fe}} \approx I_{\mathrm{Al}} \approx 1.1 I_{\mathrm{Cu}}$. It is need to point out that $k \mathrm{cu}$, $k_{F e}$, and $k_{A l}$ have dimensionalities as diffusion coefficients $\left[\mathrm{m}^{2} / \mathrm{s}\right]$, because electrochemical corrosion occurs through anodes' surface. 


\subsection{Investigation at temperature $100^{\circ} \mathrm{C}$}

Experiments were carried also at temperature $100 \circ \mathrm{C}$. Cylindrical anodes $(99.99 \% \mathrm{Cu}$, $99.99 \% \mathrm{Al}$, and $99.96 \% \mathrm{Fe}$ ) were used for copper and aluminium [10], and also iron electric corrosion investigation. Sodium chloride $(\mathrm{NaCl})$ solution was used as electrolyte (Figure 4). Direct electric current and anodes' mass decreasing rate were measured (Figure 5).

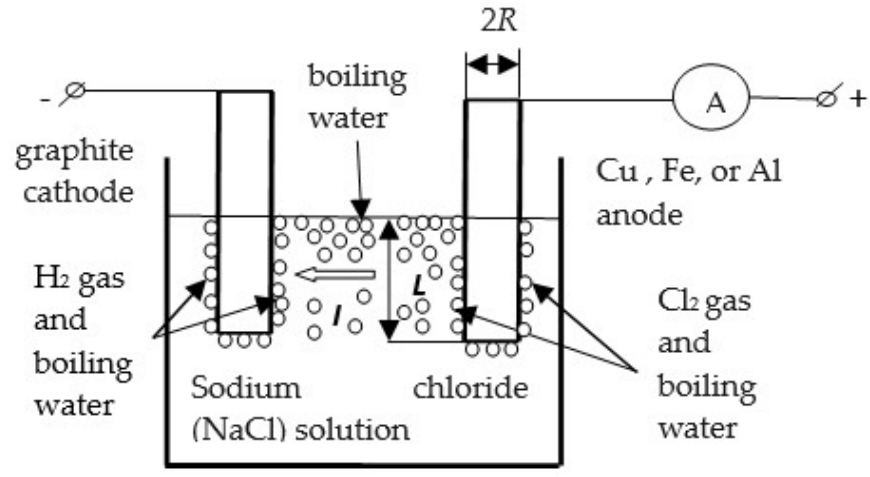

Figure 4. Scheme of experimental equipment at $\mathrm{T}=100^{\circ} \mathrm{C}$. $\mathrm{Cu}, \mathrm{Fe}$, and $\mathrm{Al}$ anodes dissolve into $\mathrm{NaCl}$ solution as $\mathrm{Cu}^{+}, \mathrm{Cu}^{2+}, \mathrm{Fe}^{2+}$, and $\mathrm{Al}^{3+}$ ions.

Electric current value did not change, so one can calculate:

$$
\begin{aligned}
& z_{C u}=\frac{63.55 \cdot 10^{-3} \mathrm{~kg} / \mathrm{mol} \cdot 3.05 \mathrm{~A} \cdot 1.2 \cdot 10^{3} \mathrm{~s}}{F \cdot \pi \cdot 8.9 \cdot 10^{3} \mathrm{~kg} / \mathrm{m}^{3} L_{C u} \cdot\left(R_{C u}^{2}(t=0)-R_{C u}^{2}\left(t_{4}\right)\right)} \approx 1.47 \approx \frac{1+2}{2}, \\
& z_{A l}=\frac{27 \cdot 10^{-3} \mathrm{~kg} / \mathrm{mol} \cdot 3.15 \mathrm{~A} \cdot 1.2 \cdot 10^{3} \mathrm{~s}}{F \cdot \pi \cdot 2.7 \cdot 10^{3} \mathrm{~kg} / \mathrm{m}^{3} L_{A l} \cdot\left(R_{A l}^{2}(t=0)-R_{A l}^{2}\left(t_{4}\right)\right)} \approx 2.85 \approx 3, \\
& z_{\mathrm{Fe}}=\frac{55.847 \cdot 10^{-3} \mathrm{~kg} / \mathrm{mol} \cdot 3.15 \mathrm{~A} \cdot 1.2 \cdot 10^{3} \mathrm{~s}}{F \cdot \pi \cdot 7.86 \cdot 10^{3} \mathrm{~kg} / \mathrm{m}^{3} L_{\mathrm{Fe}} \cdot\left(R_{\mathrm{Fe}}^{2}(t=0)-R_{\mathrm{Fe}}^{2}\left(t_{4}\right)\right)} \approx 2.01 \approx 2 \text {, }
\end{aligned}
$$

where $L_{\mathrm{Cu}}=L_{\mathrm{Al}}=4 \cdot 10^{-2} \mathrm{~m}, L_{\mathrm{Fe}}=5 \cdot 10^{-2} \mathrm{~m}, R_{0 \mathrm{Cu}}=2.27 \mathrm{~mm}, R_{0 \mathrm{Al}}=2.6 \mathrm{~mm}, R_{0 \mathrm{Fe}}=2.83 \mathrm{~mm}, I_{\mathrm{Al}}=3.15 \mathrm{~A}$, $I_{\mathrm{Fe}}=3.13 \mathrm{~A}, I_{\mathrm{Cu}}=3.05 \mathrm{~A}$, so copper dissolved into $\mathrm{NaCl}$ solution as $\mathrm{Cu}^{+}$and $\mathrm{Cu}^{2+}$ ions (copper dissolved into $\mathrm{NaCl}$ solution as $\mathrm{Cu}^{+}$ions at room temperature), iron dissolved into $\mathrm{NaCl}$ solution as the $\mathrm{Fe}^{2+}$ ions (as at room temperature), and aluminium dissolved into $\mathrm{NaCl}$ solution as $\mathrm{Al}^{3+}$ ions (as at room temperature). Anodes radii decreasing kinetics is shown on Figure 5. Experiments were carried during $t_{1}=5 \mathrm{~min}, t_{2}=10 \mathrm{~min}, t_{3}=15 \mathrm{~min}$, and $t_{4}=20 \mathrm{~min}$. Experimental results are as follows: $R_{1 \mathrm{Cu}}=2.2 \mathrm{~mm}, R_{2 \mathrm{Cu}}=2.12 \mathrm{~mm}, R_{3 \mathrm{Cu}}=2.03 \mathrm{~mm}$, $R_{4 \mathrm{Cu}}=1.92 \mathrm{~mm} ; R_{1 \mathrm{Al}}=2.56 \mathrm{~mm}, R_{2 \mathrm{Al}}=2.51 \mathrm{~mm}, R_{3 \mathrm{Al}}=2.45 \mathrm{~mm}, R_{4 \mathrm{Al}}=2.38 \mathrm{~mm} ; R_{1 \mathrm{Fe}}=2.80 \mathrm{~mm}$, $R_{2 \mathrm{Fe}}=2.76 \mathrm{~mm}, R_{3 \mathrm{Fe}}=2.72 \mathrm{~mm}, R_{4 \mathrm{Fe}}=2.67 \mathrm{~mm}$. Measurement precision was $0.01 \mathrm{~mm}$ or 10 micrometers. We carried additional experiments, but result was the same.

Chemical reactions are more complicated at $100^{\circ} \mathrm{C}$ than at room temperature near positive electrodes (anodes):

$$
\begin{aligned}
\mathrm{Cu}^{0}-e^{-}=\mathrm{Cu}^{+}, \mathrm{Cu} u^{0}-2 e^{-}=\mathrm{Cu}^{2+}, \mathrm{Al}^{0}-3 e^{-}=\mathrm{Al}^{3+}, \quad \mathrm{Fe}^{0}-2 e^{-}=\mathrm{Fe}^{2+} ; \\
\mathrm{Cu}^{+}+\mathrm{Cl}^{-}=\mathrm{CuCl} \downarrow, \mathrm{Al}^{3+}+3 \mathrm{Cl}^{-}=\mathrm{AlCl}_{3} \downarrow, \mathrm{Fe}^{2+}+2 \mathrm{Cl}^{-}=\mathrm{FeCl}_{2} \downarrow ;
\end{aligned}
$$


$\mathrm{Cu}^{2+}+2 \mathrm{Cl}^{-}=\mathrm{CuCl}_{2} \downarrow, \mathrm{Cl}^{-}-e^{-}=\mathrm{Cl}^{0}, \mathrm{Cl}^{0}+\mathrm{Cl}^{0}=\mathrm{Cl}_{2} \uparrow$.

Chlorine gas and boiling water were formed near anodes.

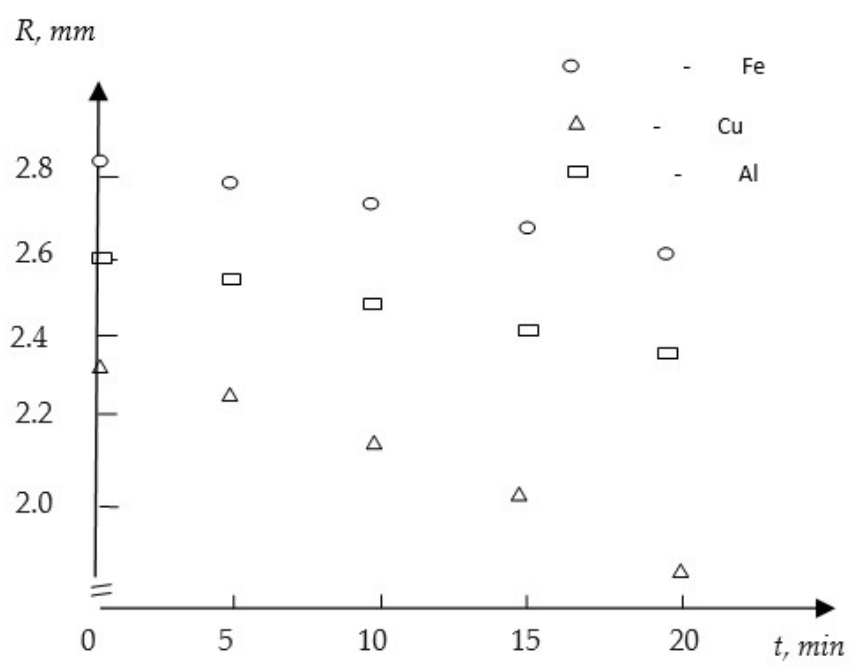

Figure 5. $\mathrm{Cu}, \mathrm{Fe}$, and $\mathrm{Al}$ anodes radii decreasing kinetics at $\mathrm{T}=100^{\circ} \mathrm{C}$.

Chemical reactions took place near negative electrodes (cathodes):

$$
\mathrm{Na}^{+}-e^{-}=\mathrm{Na}^{0}, 2 \mathrm{Na}+2 \mathrm{H}_{2} \mathrm{O}=2 \mathrm{NaOH}+\mathrm{H}_{2} \uparrow .
$$

Hydrogen gas and boiling water were formed near cathodes.

Anodes radii decreasing rate constants can be calculated as average value of four experiments to increase calculation precise:

$$
\begin{gathered}
k_{C u}=\frac{4 R_{0 C u}^{2}-\sum_{i=1}^{4} R_{i C u}^{2}}{\sum_{i=1}^{4} t_{i}} \approx 1.154 \cdot 10^{-9} \mathrm{~m}^{2} / \mathrm{s},\left\{1.25 \cdot 10^{-9} \text { at room temperature }\right\} \\
k_{A l}=\frac{4 R_{0 A l}^{2}-\sum_{i=1}^{4} R_{i A l}^{2}}{\sum_{i=1}^{4} t_{i}} \approx 8.42 \cdot 10^{-10} \mathrm{~m}^{2} / \mathrm{s},\left\{7.29 \cdot 10^{-10}\right. \text { at room temperatur }
\end{gathered}
$$

$$
k_{F e}=\frac{4 R_{0 F e}^{2}-\sum_{i=1}^{4} R_{i F e}^{2}}{\sum_{i=1}^{4} t_{i}} \approx 6.83 \cdot 10^{-10} \mathrm{~m}^{2} / \mathrm{s},\left\{7.23 \cdot 10^{-10} \text { at room temperature }\right\}, k_{C u} \approx 1.37 k_{A l},\{1.72 \text { at room temperature }
$$

$$
\left.T_{1} \approx 27^{\circ} \mathrm{C}\right\},
$$

so copper electrochemical corrosion is higher at room temperature $T_{1} \approx 27^{\circ} \mathrm{C}$, aluminium electrochemical corrosion is higher at temperature $T_{2}=100^{\circ} \mathrm{C}$, and ratio of electrochemical corrosion rates, $k \mathrm{cu}_{\mathrm{u}} / \mathrm{k}_{\mathrm{Al}}$, decreases with temperature increasing, although iron electrochemical corrosion rate practically doesn't depend on temperature below $100^{\circ} \mathrm{C}$. It is obvious, because of higher melting point of iron than melting point of copper or aluminium. We 
can conclude that the $\mathrm{Cu}^{2+}$ ions are less mobile than $\mathrm{Cu}^{+}$ions. It is need to point out that $k_{\mathrm{Cu}}, k_{\mathrm{Al}}$, and $k_{\mathrm{Fe}}$ have dimensionalities as diffusion coefficients, $D^{*} \mathrm{Cu}, D^{*} \mathrm{Al}, D^{*} \mathrm{Fe}\left[\mathrm{m}^{2} / \mathrm{s}\right]$, because electrochemical corrosion occurs through anodes' surface.

Dislocation pipe and volume diffusion activation energies can be calculated in such a way. The Arrhenius law is valid for dislocation pipe diffusion and volume diffusion in ultra high purity samples [11,19]:

$$
\begin{gathered}
D_{d}^{*}=D_{0 d} e^{-Q_{d} /(R T)} \text { or } D_{d}^{*}=D_{0 d} e^{-E_{d} /\left(k_{B} T\right)}, \text { and } D_{V}^{*}=D_{0 V} e^{-Q_{V} /(R T)} \text { or } D_{V}^{*}=D_{0 V} e^{-E_{V} /\left(k_{B} T\right)}, \\
Q[\mathrm{~J} / \mathrm{mol}]=F \cdot E[\mathrm{eV}] .
\end{gathered}
$$

Here $R \approx 8.314 \mathrm{JK}^{-1}$ is the gas constant, $k_{B}$ is the Boltzmann constant, $Q_{d}\left(E_{d}\right)$ is the dislocation pipe diffusion activation energy $\left(Q_{d}=F E_{d}\right), F \approx 96500 \mathrm{Cmol}^{-1}$ is the Faraday constant, $Q_{V}\left(E_{V}\right)$ is the volume diffusion activation energy $\left(Q_{V}=F E_{V}\right), D_{0 d}$ and $D_{0 V}$ are the preexponential factors, $T$ is absolute temperature.

Our experimental results allow to calculate:

$$
\begin{gathered}
\frac{k_{C u}}{k_{A l}}(T) \approx \frac{D_{C u}^{*}}{D_{A l}^{*}}(T)=\frac{D_{0 C u}^{*}}{D_{0 A l}^{*}} e^{\left(Q_{A l}-Q_{C u}\right) /(R T)} ; \ln \left(\frac{D_{0 C u}^{*}}{D_{0 A l}^{*}}\right)=-0.6 ; Q_{A l}-Q_{C u}=2.9 \mathrm{~kJ} / \mathrm{mol}, \\
\frac{D_{0 C u}^{*}}{D_{0 A l}^{*}}=0.55 \quad \frac{D_{C u}^{*}}{D_{A l}^{*}}\left(T_{3}\right)=1 \Rightarrow T_{3}=\frac{2900 \mathrm{~J} / \mathrm{mol}}{0.6 \mathrm{R}} \approx 583 \mathrm{~K} \approx 310^{\circ} \mathrm{C},
\end{gathered}
$$

so diffusion activation energy of $\mathrm{Al}, \mathrm{Q}_{\mathrm{Al}}$, is higher than diffusion activation energy of $\mathrm{Cu}$, $Q_{\mathrm{Cu}},\left(Q_{\mathrm{Al}}>Q_{\mathrm{Cu}}, Q_{\mathrm{Al}}-Q_{\mathrm{Cu}}=2.9 \mathrm{~kJ} / \mathrm{mol}\right)$, at temperatures from $20^{\circ} \mathrm{C}$ to $100^{\circ} \mathrm{C}$, because the $\mathrm{Cu}^{+}$ ions have higher mobilities than the $\mathrm{Al}^{3+}$ ions, and copper electrochemical corrosion rate can be approximately equal to aluminium electrochemical corrosion at temperature about $T_{3} \approx 300^{\circ} \mathrm{C}$ due to the $\mathrm{Cu}^{2+}$ ions are less mobile than the $\mathrm{Cu}^{+}$ions. Moreover, the pre-exponential factors are approximately the same: $D^{*}{ }_{0 \mathrm{Al}} \approx 2 D^{*}{ }_{0 \mathrm{Cu}}$.

\section{Intrinsic diffusivities ratio and diffusion activation energy calculations}

\subsection{Intrinsic diffusivities ratio of $\mathrm{Cu}$ and $\mathrm{Al}$ analysis}

We can analyse described experimental results in the Al-Cu system for bulk samples [12], since the ratio $D^{*} \mathrm{Al} / D^{*} \mathrm{Cu}$ didn't calculated in [12]:

$$
\frac{D_{C u}^{*}}{D_{A l}^{*}} \approx \frac{\sum_{j=1}^{N} X_{j}-X_{K}\left(1-C_{i}\right) \sqrt{\pi}}{\sum_{j=1}^{N} X_{j}+C_{i} X_{K} \sqrt{\pi}}<1, \quad C_{i}=C_{\mathrm{Al}},
$$

where $N$ is formed phases quantity, $X_{j}$ is phase $j^{\prime}$ s thickness, $C_{i}$ is is the average concentration of aluminium in phase $i, X_{K}$ is the Kirkendall shift length.

Five phases are formed in the Al-Cu system at temperatures from $400^{\circ} \mathrm{C}$ to $535^{\circ} \mathrm{C}$ in bulk samples [12]: $\theta$-phase (phase 1) $\mathrm{CuAl}_{2}\left(C_{1}=2 / 3\right), \eta_{2}$-phase (phase 2) $\mathrm{CuAl}\left(C_{2}=1 / 2\right), \zeta_{2}-$ phase (phase $3 b$ ) $\mathrm{Cu}_{4} \mathrm{Al}_{3}\left(C_{3 b}=3 / 7\right)$, $\delta$-phase (phase $3 a$ ) $\mathrm{Cu}_{3} \mathrm{Al}_{2}\left(C_{3 a}=2 / 5\right)$, and $\gamma_{2}$-phase (phase 3) $\mathrm{Cu}_{9} \mathrm{Al}_{4}\left(C_{3}=4 / 13 \approx 0.31 \approx 1 / 3, C=C_{A l}\right)$. Inert markers were in $\delta$-phase (phase $\left.3 a\right) \mathrm{Cu}_{3} \mathrm{Al}_{2}$ $\left(C_{3 a}=2 / 5=0.4\right)$ and moved to Al side during mutual diffusion. In general, inert markers move to faster diffusivity component side. We can calculate $\left(C_{3 a}=0.4\right)$ :

$$
\begin{gathered}
\frac{D_{C u}^{*}}{D_{A l}^{*}}\left(T_{1}=535^{\circ} C\right) \approx \frac{X_{1}+X_{2}+X_{3 b}+X_{3 a}+X_{3}-X_{K} 0.6 \sqrt{\pi}}{X_{1}+X_{2}+X_{3 b}+X_{3 a}+X_{3}+0.4 X_{K} \sqrt{\pi}} \approx 0.814 ; y_{1}=\frac{D_{A l}^{*}}{D_{C u}^{*}}=\frac{1}{0.814} \approx 1.228, \\
T_{1}=535^{\circ} \mathrm{C}=808 \mathrm{~K}, t=40 \mathrm{~h}, X_{K} \approx 20.5 \mu \mathrm{m}, X_{1}+X_{2}+X_{3 b}+X_{3 a}+X_{3} \approx 180 \mu \mathrm{m} ; \\
\frac{D_{C u}^{*}}{D_{A l}^{*}}\left(T_{2}=515^{\circ} C\right) \approx \frac{X_{1}+X_{2}+X_{3 b}+X_{3 a}+X_{3}-X_{K}\left(1-C_{3 a}\right) \sqrt{\pi}}{X_{1}+X_{2}+X_{3 b}+X_{3 a}+X_{3}+C_{3 a} X_{K} \sqrt{\pi}} \approx 0.856 ; y_{2}=\frac{D_{A l}^{*}}{D_{C u}^{*}} \approx 1.168,
\end{gathered}
$$




$$
\begin{gathered}
\left.T_{2}=515^{\circ} \mathrm{C}=788 \mathrm{~K}, t=40 \mathrm{~h}, X_{K} \approx 11 \mu \mathrm{m}, X_{1}+X_{2}+X_{3 b}+X_{3 a}+X_{3} \approx 127 \mu \mathrm{m}\right) ; \\
\frac{D_{C u}^{*}}{D_{A l}^{*}}\left(T_{3}=495^{\circ} \mathrm{C}\right) \approx \frac{X_{1}+X_{2}+X_{3 b}+X_{3 a}+X_{3}-X_{K} 0.6 \sqrt{\pi}}{X_{1}+X_{2}+X_{3 b}+X_{3 a}+X_{3}+0.4 X_{K} \sqrt{\pi}} \approx 0.916 ; y_{3}=\frac{1}{0.916} \approx 1.092, \\
T_{3}=495^{\circ} \mathrm{C}=768 \mathrm{~K}, t=40 \mathrm{~h}, X_{K} \approx 5 \mu \mathrm{m}, X_{1}+X_{2}+X_{3 b}+X_{3 a}+X_{3} \approx 101 \mu \mathrm{m} ; \\
\frac{D_{C u}^{*}}{D_{A l}^{*}}\left(T_{4}=475^{\circ} \mathrm{C}\right) \approx \frac{X_{1}+X_{2}+X_{3 b}+X_{3 a}+X_{3}-X_{K}(1-0.4) \sqrt{\pi}}{X_{1}+X_{2}+X_{3 b}+X_{3 a}+X_{3}+0.4 C X_{K} \sqrt{\pi}} \approx 0.969 ; y_{4}=\frac{D_{A l}^{*}}{D_{C u}^{*}} \approx 1.032, \\
T_{4}=475^{\circ} \mathrm{C}=748 \mathrm{~K}, t=90 \mathrm{~h}, X_{K} \approx 2 \mu \mathrm{m}, X_{1}+X_{2}+X_{3 b}+X_{3 a}+X_{3} \approx 113 \mu \mathrm{m} .
\end{gathered}
$$

We can use these four points to calculate by the least square method to increase calculation precise:

$$
\begin{aligned}
& \Delta Q=Q_{A l}-Q_{C u}=\frac{4 \sum_{j=1}^{4}\left(\frac{1000}{R T_{j}} \ln y_{j}\right)-\sum_{j=1}^{4} \ln y_{j} \sum_{j=1}^{4} \frac{1000}{R T_{j}}}{4 \sum_{j=1}^{4}\left(\frac{1000}{R T_{j}}\right)^{2}-\left(\sum_{j=1}^{4} \frac{1000}{R T_{j}}\right)^{2}} \approx-13.4 \mathrm{~kJ} / \mathrm{mol} \\
& y_{0}=\exp \frac{\sum_{j=1}^{4}\left(\frac{1000}{R T_{j}}\right)^{2} \sum_{j=1}^{4} \ln y_{j}-\sum_{j=1}^{4} \frac{1000}{R T_{j}} \sum_{j=1}^{4}\left(\frac{1000}{R T_{j}} \ln y_{j}\right)}{4 \sum_{j=1}^{4}\left(\frac{1000}{R T_{j}}\right)^{2}-\left(\sum_{j=1}^{4} \frac{1000}{R T_{j}}\right)^{2}} \approx \exp (2.2) \approx 9 \\
& \frac{D_{A l}^{*}}{D_{C u}^{*}}(T)=\frac{D_{0 A l}^{*}}{D_{0 C u}^{*}} e^{\left(Q_{A l}-Q_{C u}\right) /(R T)} \approx 9 e^{-13.4 k^{\prime m o l} l^{-1} /(R T)}, \\
& \frac{D_{A l}^{*}}{D_{C u}^{*}}\left(T_{5}\right)=y_{5}=1 \Rightarrow T_{5}=\frac{13400 \mathrm{~J} / \mathrm{mol}}{R \ln 9} \approx 733 \mathrm{~K} \approx 460{ }^{\circ} \mathrm{C}
\end{aligned}
$$

so $Q_{\mathrm{Al}}<Q_{\mathrm{Cu}}\left(Q_{\mathrm{Al}}-Q_{\mathrm{Cu}}=-13.4 \mathrm{~kJ} / \mathrm{mol}\right)$ because the $\mathrm{Cu}^{2+}$ ions have less mobilities than the $\mathrm{Al}^{3+}$ ions, and we can conclude that the Kirkendall displacement changes sign at temperature about $T_{5} \approx 460^{\circ} \mathrm{C}$ for bulk samples. The pre-exponential factors are different in nine times: $D^{*}{ }_{0 \mathrm{Al}} \approx 9 D^{*}{ }_{0 \mathrm{Cu}}$.

Diffusion activation energy of $\mathrm{Al}$ is less than diffusion activation energy of $\mathrm{Cu}$ $\left(Q_{\mathrm{Al}}<Q_{\mathrm{Cu}}\right)$ at temperatures from $160^{\circ} \mathrm{C}$ to $250^{\circ} \mathrm{C}$ for mutual diffusion in copper-aluminium thin film double layers, but the pre-exponential factors are different in tens times [14]. Isolated $\mathrm{W}$ islands, $150 \AA$ in diameter, have been deposited between $\mathrm{Cu}$ and $\mathrm{Al}$ thin film double layers to serve as inert diffusion markers. Marker displacements have been measured. We can calculate ratio $D^{*} \mathrm{Al} / D^{*} \mathrm{Cu}$ for each phase at different temperatures:

$$
\begin{gathered}
\left.\frac{D_{C u}^{*}}{D_{A l}^{*}}(T)=\frac{D_{0 C u}^{*}}{D_{0 A l}^{*}} e^{\left(Q_{A l}-Q_{C u}\right) /(R T)}=24 e^{-14 \mathrm{kJmol}^{-1} /(R T)} \text { in } \theta \text {-phase (phase } 1\right) \mathrm{CuAl}_{2}, C_{A l}=2 / 3 \approx 0.67 \\
\frac{D_{1 C u}^{*}}{D_{1 A l}^{*}}\left(T=250^{\circ} \mathrm{C}=523 \mathrm{~K}\right)=24 e^{-14000 \mathrm{Jmol}^{-1} /(8.314 \times 523)} \approx 24 e^{-3.22} \approx 0.96 \\
\frac{D_{1 \mathrm{Cu}}^{*}}{D_{1 \mathrm{Al}}^{*}}\left(T=160^{\circ} \mathrm{C}=433 \mathrm{~K}\right) \approx 24 e^{-3.89} \approx 0.49
\end{gathered}
$$


so the $\mathrm{Al}$ atoms diffuse faster than the $\mathrm{Cu}$ atoms in $\theta$-phase at temperatures from $160^{\circ} \mathrm{C}$ to $250^{\circ} \mathrm{C}$;

$$
\begin{gathered}
\frac{D_{C u}^{*}}{D_{A l}^{*}}(T)=\frac{D_{0 C u}^{*}}{D_{0 A l}^{*}} e^{\left(Q_{A l}-Q_{C u}\right) /(R T)}=7 \cdot 10^{4} e^{-38 \mathrm{kJmol}^{-1} /(R T)} \text { in } \eta_{2} \text {-phase (phase 2) CuAl, } C_{\mathrm{Al}}=1 / 2=0.5 \\
\frac{D_{2 C u}^{*}}{D_{2 A l}^{*}}\left(T=250^{\circ} \mathrm{C}\right)=7 \cdot 10^{4} e^{-38000 \mathrm{Jmol}^{-1} /(R T)} \approx 11.2, \quad \frac{D_{2 C u}^{*}}{D_{2 A l}^{*}}\left(T=160^{\circ} \mathrm{C}\right) \approx 1.8
\end{gathered}
$$

so the $\mathrm{Cu}$ atoms diffuse faster than the $\mathrm{Al}$ atoms in $\eta_{2}$-phase at temperatures from $160^{\circ} \mathrm{C}$ to $250^{\circ} \mathrm{C}$;

$$
\begin{gathered}
\frac{D_{C u}^{*}}{D_{A l}^{*}}(T)=\frac{D_{0 C u}^{*}}{D_{0 A l}^{*}} e^{\left(Q_{A l}-Q_{C u}\right) /(R T)}=14 e^{-9 \mathrm{kJmol}^{-1} /(R T)} \text { in } \gamma_{2} \text {-phase (phase 3) } \mathrm{Cu}_{9} \mathrm{Al}_{4}, C_{\mathrm{Al}}=4 / 13 \approx 0.31, \\
\frac{D_{3 C u}^{*}}{D_{3 A l}^{*}}\left(T=250^{\circ} \mathrm{C}\right)=14 e^{-9000 \mathrm{Jmol}^{-1} /(R T)} \approx 1.77 \quad \frac{D_{3 C u}^{*}}{D_{3 \mathrm{Al}}^{*}}\left(T=160^{\circ} \mathrm{C}\right)=14 e^{-9 \mathrm{kJmol}-1 /(R T)} \approx 1.15
\end{gathered}
$$

so the $\mathrm{Cu}$ atoms diffuse faster than the $\mathrm{Al}$ atoms in $\gamma_{2}$-phase at temperatures from $160^{\circ} \mathrm{C}$ to $250^{\circ} \mathrm{C}$.

The $\mathrm{Cu}$ rich phases can be formed faster than the $\mathrm{Al}$ rich phases at temperatures from $160^{\circ} \mathrm{C}$ to $250^{\circ} \mathrm{C}$, and the $\mathrm{Cu}$ atoms can diffuse faster than the $\mathrm{Al}$ atoms in the $\mathrm{Al}-\mathrm{Cu}$ system at temperatures from $160^{\circ} \mathrm{C}$ to $250^{\circ} \mathrm{C}$. The $\mathrm{Al}$ rich phases can be formed faster than the $\mathrm{Cu}$ rich phases at temperatures from $400^{\circ} \mathrm{C}$ to $535^{\circ} \mathrm{C}$, and the $\mathrm{Al}$ atoms can diffuse faster than the $\mathrm{Cu}$ atoms in the $\mathrm{Al}-\mathrm{Cu}$ system at temperatures from $400^{\circ} \mathrm{C}$ to $535^{\circ} \mathrm{C}$. It depends on the crystal structure of each phase, but, in general, it could depends on conclusions that the $\mathrm{Cu}^{2+}$ ions are less mobile than the $\mathrm{Cu}+$ ions, and the ratio $D^{*}{ }_{A l} / D^{*} \mathrm{Cu}$ depends on temperature.

\subsection{Diffusion activation energy calculation}

3.2.1 Diffusion activation energy calculation in the $\mathrm{Cu}-\mathrm{Al}$ system

Mutual diffusion coefficients were calculated for all five phases [12]:

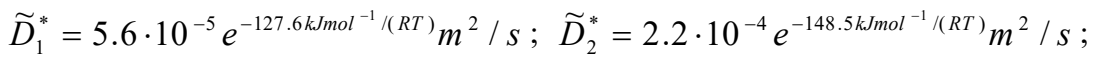

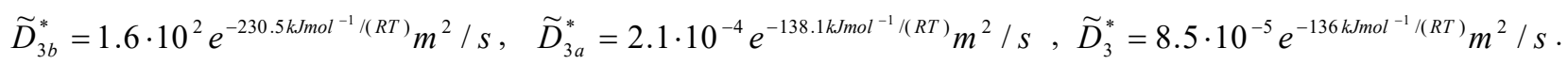

We can see that $Q_{1}<Q_{2}, Q_{1}<Q_{3}$, and $Q_{3}<Q_{2}$ because of $K_{1}>K_{2}, K_{1}>K_{3}$, and $K_{3}>K_{2}$, and $D_{01} \approx D_{02} \approx D_{03}$. Phase $j$ 's rate formation is $K_{j}$. Three phases are formed in the Al-Cu system at temperatures $300^{\circ} \mathrm{C}$ and $350^{\circ} \mathrm{C}$ [15]: $\mathrm{CuAl}_{2}, \mathrm{CuAl}$, and $\mathrm{Cu}_{9} \mathrm{Al}_{4}$. Phases formation rates were experimentally measured: $K_{1}=860 \times 10^{-18} \mathrm{~m}^{2} / \mathrm{s}, K_{2}=100 \times 10^{-18} \mathrm{~m}^{2} / \mathrm{s}$, and $K_{3}=360 \times 10^{-18} \mathrm{~m}^{2} / \mathrm{s}$ at temperature $350^{\circ} \mathrm{C} ; K_{1}=77 \times 10^{-18} \mathrm{~m}^{2} / \mathrm{s}, K_{2}=18 \times 10^{-18} \mathrm{~m}^{2} / \mathrm{s}$, and $K_{3}=35 \times 10^{-18} \mathrm{~m}^{2} / \mathrm{s}$ at temperature $300^{\circ} \mathrm{C}$, so $K_{1}>K_{2}, K_{1}>K_{3}$, and $K_{3}>K_{2}$. We can calculate assuming $C_{1}=2 / 3, C_{2}=1 / 2, C_{3}=1 / 3$, $C=C_{\mathrm{Al}}[4]$ :

$$
\begin{aligned}
& D_{1} \approx \frac{1}{2}\left(C_{1}\left(1-C_{1}\right) K_{1}+C_{2}\left(1-C_{1}\right) \sqrt{K_{1} K_{2}}+C_{3}\left(1-C_{1}\right) \sqrt{K_{1} K_{3}}\right) \\
& D_{2} \approx \frac{1}{2}\left(C_{2}\left(1-C_{2}\right) K_{2}+C_{2}\left(1-C_{1}\right) \sqrt{K_{1} K_{2}}+C_{3}\left(1-C_{2}\right) \sqrt{K_{2} K_{3}}\right)
\end{aligned}
$$




$$
\begin{gathered}
D_{3} \approx \frac{1}{2}\left(C_{3}\left(1-C_{3}\right) K_{3}+C_{3}\left(1-C_{1}\right) \sqrt{K_{1} K_{3}}+C_{3}\left(1-C_{2}\right) \sqrt{K_{2} K_{3}}\right) \\
D_{1}\left(T_{2}=350^{\circ} C\right) \approx \frac{1}{9} K_{1}+\frac{1}{12} \sqrt{K_{1} K_{2}}+\frac{1}{18} \sqrt{K_{1} K_{3}} \approx 150 \cdot 10^{-18} \mathrm{~m}^{2} / \mathrm{s}, D_{1}\left(T_{1}=300^{\circ} \mathrm{C}\right) \approx 15 \cdot 10^{-18} \mathrm{~m}^{2} / \mathrm{s} \\
D_{2}\left(T_{2}=350^{\circ} \mathrm{C}\right) \approx \frac{1}{8} K_{2}+\frac{1}{12} \sqrt{K_{1} K_{2}}+\frac{1}{12} \sqrt{K_{2} K_{3}} \approx 50 x 10^{-18} \mathrm{~m}^{2} / \mathrm{s}, \quad D_{2}\left(T_{1}=300^{\circ} \mathrm{C}\right) \approx 8 \cdot 10^{-18} \mathrm{~m}^{2} / \mathrm{s} \\
D_{3}\left(T_{2}=350^{\circ} \mathrm{C}\right) \approx \frac{1}{9} K_{3}+\frac{1}{18} \sqrt{K_{1} K_{3}}+\frac{1}{12} \sqrt{K_{2} K_{3}} \approx 90 \cdot 10^{-18} \mathrm{~m}^{2} / \mathrm{s}, \quad D_{3}\left(T_{1}=300^{\circ} \mathrm{C}\right) \approx 12 \cdot 10^{-18} \mathrm{~m}^{2} / \mathrm{s}
\end{gathered}
$$

Authors [15] didn't calculate diffusion activation energies and the pre-exponential factors, so we can do it:

$$
\begin{gathered}
Q_{i}=\frac{R T_{1} T_{2}}{T_{2}-T_{1}} \ln \left(\frac{D_{i}\left(T_{2}\right)}{D_{i}\left(T_{1}\right)}\right), \quad D_{0 i}=D_{i}\left(T_{1}\right) e^{Q_{i} /\left(R T_{1}\right)}=D_{i}\left(T_{2}\right) e^{Q_{i} /\left(R T_{2}\right)} ; \\
\widetilde{D}_{1}=4.3 \cdot 10^{-5} e^{-136.7 \mathrm{kJmol}^{-1} /(R T)} \mathrm{m}^{2} / \mathrm{s}, \widetilde{D}_{2}=6.6 \cdot 10^{-8} e^{-108.8 \mathrm{kJmol}^{-1} /(R T)} \mathrm{m}^{2} / \mathrm{s}, \\
\widetilde{D}_{3}=9.6 \cdot 10^{-7} e^{-119.6 \mathrm{kJmol}^{-1} /(R T)} \mathrm{m}^{2} / \mathrm{s} .
\end{gathered}
$$

Equations (39) correspond to Equations (31). We can use several, N, points to calculate by the least square method to increase calculation precise:

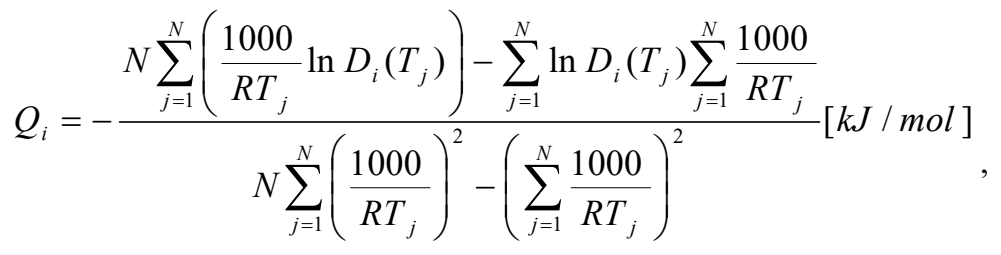

$$
\begin{aligned}
& D_{0 i}=\exp \frac{\sum_{j=1}^{5}\left(\frac{1000}{R T_{j}}\right)^{2} \sum_{j=1}^{5} \ln D_{i}\left(T_{j}\right)-\sum_{j=1}^{5} \frac{1000}{R T_{j}} \sum_{j=1}^{4}\left(\frac{1000}{R T_{j}} \ln D_{i}\left(T_{j}\right)\right)}{5 \sum_{j=1}^{5}\left(\frac{1000}{R T_{j}}\right)^{2}-\left(\sum_{j=1}^{5} \frac{1000}{R T_{j}}\right)^{2}}\left[m^{2} / \mathrm{s}\right]
\end{aligned}
$$

Equations (40) and (41) give Equations (38) for only two points (N=2).

\subsubsection{Diffusion activation energy calculation in pure iron}

A method of dislocation pipe diffusion parameters determination during the type B diffusion kinetics was suggested by model of dislocation pipe diffusion involving outflow [11]. The method involves diffusion dislocation pipe kinetics for two different annealing times at the same temperature during the type B kinetics and dislocation pipe kinetics for one annealing time at other lower temperature during the type $C$ kinetics. Transition time for type B kinetics to type A kinetics (volume diffusion) and kinetics law $t^{1 / 6}$ [17] for cone top rate are used in this method.

Bulk diffusion coefficients, $D_{V}$, for the diffusion of ${ }^{59} \mathrm{Fe}$ in the high purity iron were calculated in [16] using type $B \rightarrow$ A kinetics: $D_{V}=1.5^{*} 10^{-18} \mathrm{~m}^{2} \mathrm{~s}^{-1}$ at $T_{1}=973 \mathrm{~K}$ for $\mathrm{t} B \rightarrow \mathrm{A}=67.5 \mathrm{ks}$ ( $T_{m} / T_{1}=1.86, T_{m}$ is melting point of iron). Only one experiment was carried out at the same 
temperature for two annealing times $t_{1}$ and $t_{2}\left(t_{1}<<t_{2}, t_{2}=40 t_{1}\right)$. Dislocation diffusion coefficients for the diffusion of ${ }^{59} \mathrm{Fe}$ in the iron were calculated in [16] using type $\mathrm{C}$ kinetics: $D_{d}=3 * 10^{-16} \mathrm{~m}^{2} \mathrm{~s}^{-1}$ at $T_{2}=753 \mathrm{~K}$ for $t_{c}=2.4 \mathrm{ks}\left(T_{m} / T_{2}=2.4\right)$. One can find ratio $D_{d} / D_{V}:{ }^{y\left(t_{C \rightarrow B}\right)=\sqrt{\frac{D_{d}}{6 D}} \delta}$ , where $\delta=1 \mathrm{~nm}, \frac{D_{d}}{D}=4.3 \times 10^{6}$. Ratio $D_{d} / D_{V}$ increases remarkably for lower temperature. Dislocation pipe and volume diffusion activation energies and pre-exponential factors didn't were calculated in [16]. It is possible to calculate $E_{d}$ and $D_{0}: \quad E_{d}=\ln \left(\frac{D_{d}\left(T_{1}\right)}{D_{d}\left(T_{2}\right)}\right) k_{B} \frac{T_{1} T_{2}}{T_{1}-T_{2}}$ , $D_{0}=D_{d}\left(T_{1}\right) \exp \left(\frac{E_{d}}{k_{B} T_{1}}\right), E_{d}=1.1 \mathrm{eV} ; Q_{d}=106 \mathrm{~kJ} / \mathrm{mol}, D_{0}=6.85 \cdot 10^{-9} \mathrm{~m}^{2} \mathrm{~s}^{-1}$. One can calculate dislocation pipe diffusion coefficient for temperature973 $\mathrm{K}$ directly $\left(T_{1}=753 \mathrm{~K}\right.$ and $T_{2}=693$ $\mathrm{K}$ (type C kinetics)): $D_{d} \approx 10^{-14} \mathrm{~m}^{2} \mathrm{~s}^{-1}$. Such value corresponds to value calculated using proposed method. The Fisher law $\left(t^{1 / 4}\right)$ gives: $D_{d} \approx 10^{-16} \div 10^{-15} \mathrm{~m}^{2} \mathrm{~s}^{-1}$. Such value is in two orders lower than experimentally obtained in [16]. The volume diffusion activation energy $E_{V}$ can be calculated: $E_{V}=\ln \left(\frac{D_{0}}{D_{V}\left(T_{1}\right)}\right) k_{B} T_{1}, E_{V}=1.85 \mathrm{eV} ; Q_{V} \approx 179 \mathrm{~kJ} / \mathrm{mol}$. Ratio $\frac{E_{d}}{E_{V}}=0.6$ as described in [19].

\section{Conclusions}

The $\mathrm{Al}$ atoms diffuse faster than the $\mathrm{Cu}$ atoms at temperature higher than $475^{\circ} \mathrm{C}$, but the $\mathrm{Cu}$ atoms diffuse faster than the $\mathrm{Al}$ atoms at temperature lower than $100^{\circ} \mathrm{C}$. Diffusion activation energy of $\mathrm{Al}$ is less than diffusion activation energy of $\mathrm{Cu}$ at temperature higher than $475^{\circ} \mathrm{C}$, but diffusion activation energy of $\mathrm{Cu}$ is less than diffusion activation energy of $\mathrm{Al}$ at temperature lower than $100^{\circ} \mathrm{C}$. Our investigations show that it is possible, because the $\mathrm{Cu}^{2+}$ ions are less mobile than $\mathrm{Cu}^{+}$ions.

Volume diffusion activation energy of Fe is higher that volume diffusion activation energy of $\mathrm{Cu}$ or $\mathrm{Al}$, but dislocation pipe diffusion activation energy of $\mathrm{Fe}$ is smaller that volume diffusion activation energy of $\mathrm{Cu}$ or $\mathrm{Al}$, so the Fe atoms diffuse faster along dislocation line, but the $\mathrm{Cu}$ or $\mathrm{Al}$ atoms diffuse faster in volume.

\section{References}

1. Kizaki T, O M, Kajihara M. Rate-Controlling Process of Compound Growth in Cu-Clad Al Wire during Isothermal Annealing at 483-543 K. Materials Transactions. 2020;61(1):188-194. DOI: https://10.2320/matertrans.MT-M2019207

2. Goh CS, Chong W L E, Lee TK, Breach C. Corrosion Study and Intermetallics Formation in Gold and Copper Wire Bonding in Microelectronics Packaging. Crystals. 2013;3(3):391-404. DOI: https://doi.org/10.3390/cryst3030391

3. Yarmolenko MV. Copper and aluminum electric corrosion investigation and intermetallics disappearance in $\mathrm{Cu}-\mathrm{Al}$ system analysis. Phys. Chem. Solid St. 2020;21(2):294-299. https://journals.pnu.edu.ua/index.php/pcss/article/view/3055

4. Yarmolenko MV. Intermetallics Disappearance Rate Analysis in Double Multiphase Systems. DDF. 2021;407:68-86. https://doi.org/10.4028/www.scientific.net/ddf.407.68

5. Włodarczyk PP, Włodarczyk B. Effect of Hydrogen and Absence of Passive Layer on Corrosive Properties of Aluminium Alloys. Materials. 2020; 13(7): 1580-1593. https://doi.org/10.3390/ma13071580

6. Kumar S, Handwerker CA, Dayananda MA. Intrinsic and Interdiffusion in Cu-Sn System. JPEDAV. 2011;32:309-319. DOI: 10.1007/s11669-011-9907-91547-7037

7. Tu KN. Electronic Thin-Film Reliability. $1^{\text {st }}$ ed. Cambridge University Press: New York; 2010. 392 p. DOI: https://www.amazon.com/Electronic-Thin-Film-Reliability-King-Ning-Tu-ebook-dp-B00QIT3LXA/dp/B00QIT3LXA/ref=mt_other?_encoding $=$ UTF8\&me $=\& q i d=$

8. Epishin A, Chyrkin A, Camin B, Saillard R, Gouy S, Viguier B. Interdiffusion in CMSX-4 Related Ni-Base Alloy System at a Supersolvus Temperature. DDF. 2021;407:1-10. https://doi.org/10.4028/www.scientific.net/ddf.407.1

9. Prawoto Y. Synergy of erosion and galvanic effects of dissimilar steel welding: Field failure analysis case study and laboratory test results. Journal of King Saud University - Engineering Sciences. 2013;25:59-64. https://doi.org/10.1016/j.jksues.2011.12.001

10. Yarmolenko MV. Intrinsic Diffusivities Ratio Analysis in the Al-Cu System. Phys. Chem. Solid St. 2020;21(4):720-726. https://journals.pnu.edu.ua/index.php/pcss/article/view/4440

11. Yarmolenko MV. Method of Dislocation and Bulk Diffusion Parameters Determination. Metallofiz. Noveishie Tekhnol.. 2020;42(11): 1537-1546. https://mfint.imp.kiev.ua/article/v42/i11/MFiNT.42.1537.pdf 
12. Funamizu Y, Watanabe K. Interdiffusion in the Al-Cu System. Transactions of the Japan Institute of Metals. 1971;12(3):147152. 10.2320/matertrans 1960.12 .147

13. Yarmolenko MV. Intermetallics Disappearance Rates and Intrinsic Diffusivities Ratios Analysis in the Cu-Zn and the Cu-Sn Systems. Phys. Chem. Solid St. 2021;22(1):80-87. https://journals.pnu.edu.ua/index.php/pcss/article/view/4744

14. Hentzell HTG, Tu KN. Interdiffusion in copper-aluminum thin film bilayers. II. Analysis of marker motion during sequential compound formation. Journal of Applied Physics. 1983;54:6929-6937. https://doi.org/10.1063/1.332000

15. Moisy F, Sauvage X, Hug E. Investigation of the early stage of reactive interdiffusion in the Cu-Al system by in-situ transmission electron microscopy. Materialia. 2020;9: 100633. https://doi.org/10.1016/j.mtla.2020.100633

16. Shima Y, Ishikawa Y, Nitta H, Yamazaki Y, Mimura K, Isshiki M, Iijima Y. Self-Diffusion along Dislocations in Ultra High Purity Iron. Materials Transactions. 2002;43(2): 173-177. https://www.jim.or.jp/journal/e/43/02/173.html

17. Yarmolenko MV. Intermediate phase cone growth kinetics along dislocation pipes inside polycrystal grains. AIP Advances. 2018;8: 095202. https://doi.org/10.1063/1.5041728

18. Yarmolenko MV. Analytically Solvable Differential Diffusion Equations Describing the Intermediate Phase Growth. Metallofiz. Noveishie Tekhnol.. 2018;40(9): 1201-1207. https://mfint.imp.kiev.ua/article/v40/i09/MFiNT.40.1201.pdf

19. Mehrer H. Diffusion in Solids. New York: Springer; 2007. 651 p. http://users.encs.concordia.ca/ tmg/images/7/79/Diffusion_in_solids_Helmut_Mehrer.pdf

20. Braunovic M. and Alexandrov N. Intermetallic compounds at aluminum-to-copper electrical interfaces: effect of temperature and electric current. IEEE Transactions on Components, Packaging, and Manufacturing Technology: Part A. 1994;17(1): 78-85. doi: $10.1109 / 95.296372$

21. Darken LS. Diffusion, mobility and their interrelation through free energy in binary metallic systems. Transactions AIME .1948;175: 184-201. http://garfield.library.upenn.edu/classics1979/A1979HJ27500001.pdf 